\title{
EDITORIAL
}

\section{Welcome to 2021}

\section{Andrew Leask ${ }^{1}$}

Published online: 25 January 2021

(c) The International CCN Society 2021

It has been an interesting year. In March 2020, I wrote a Commentary on JCCS outlining the history of how I came to be associated with the ICCNS and JCCS (Leask 2020a). I can update this Commentary by stating that the acceptance rate for JCCS is now $\sim 15 \%$. JCCS is attracting high quality papers, the majority of which specifically focus of the role of the microenvironment in disease. This commentary was written prior to COVID; in May, I wrote a Bits and Bytes highlighting the potential use of IL-6 antagonists to treat the cytokine storm in COVID (Leask 2020b). Initial studies testing this idea in patients were unsuccessful; recently, however, a non-peer reviewed paper on MedRxiv suggested that IL-6 receptor antagonists are useful to treat severe COVID cases (REMAP-CAP Investigators, Gordon 2021), and such a therapy is now being encouraged in the UK (https://www. bioworld.com/articles/502144-further-data-show-il-6-inhib itors-may-provide-covid-19-benefit-after-all). I hope to be able to write more similar articles for JCCS in my new role (Perbal 2021).

ICCNS and JCCS were the brainchildren of Bernard Perbal, and without his energy and drive, neither would exist, to the detriment of us who are driven to solve difficult problems in science, and not picking low-hanging fruit. All one has to do is examine all the editorials written in JCCS (and CCS!) to see evidence of this. It will be tough to fill those shoes.

Acknowledgements I thank Bernard and Annick Perbal for critical comments on this article.

\section{References}

Leask A (2020a) What a long, strange trip it's been. J Cell Commun Signal 14(1):19-20. https://doi.org/10.1007/s12079-020-00555-6 Leask A (2020b) COVID-19: is fibrosis the killer? J Cell Commun Signal 14(2):255. https://doi.org/10.1007/s12079-020-00569-0

Perbal B (2021) 2021: a new turn for JCCS. J Cell Commun Signal. https://doi.org/10.1007/s12079-021-00604-8

REMAP-CAP Investigators, Gordon AC (2021) Interleukin-6 receptor antagonists in critically ill patients with covid-19 MedRxiv preprint server https://doi.org/10.1101/2021.01.07.21249390

Publisher's Note Springer Nature remains neutral with regard to jurisdictional claims in published maps and institutional affiliations.
Andrew Leask

an1312@usask.ca

1 College of Dentistry, University of Saskatchewan, 105 Wiggins Rd, Saskatoon, SK, Canada 